
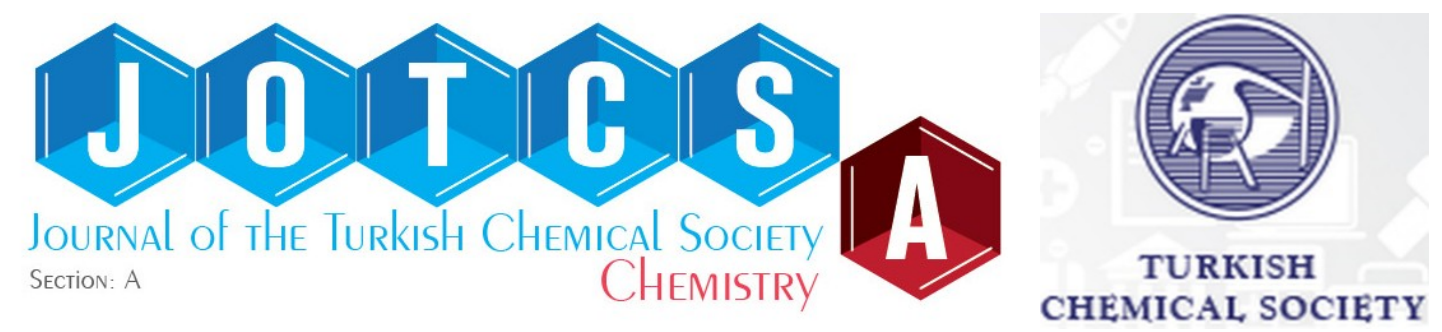

\title{
Electrochemical and in-situ spectroelectrochemical behaviors of non- peripherally tetra substituted zinc(II) and magnesium(II) phthalocyanines
}

\author{
Duygu AKYÜZ *
}

Department of Chemistry, Faculty of Science, Gebze Technical University, Kocaeli, Turkey.

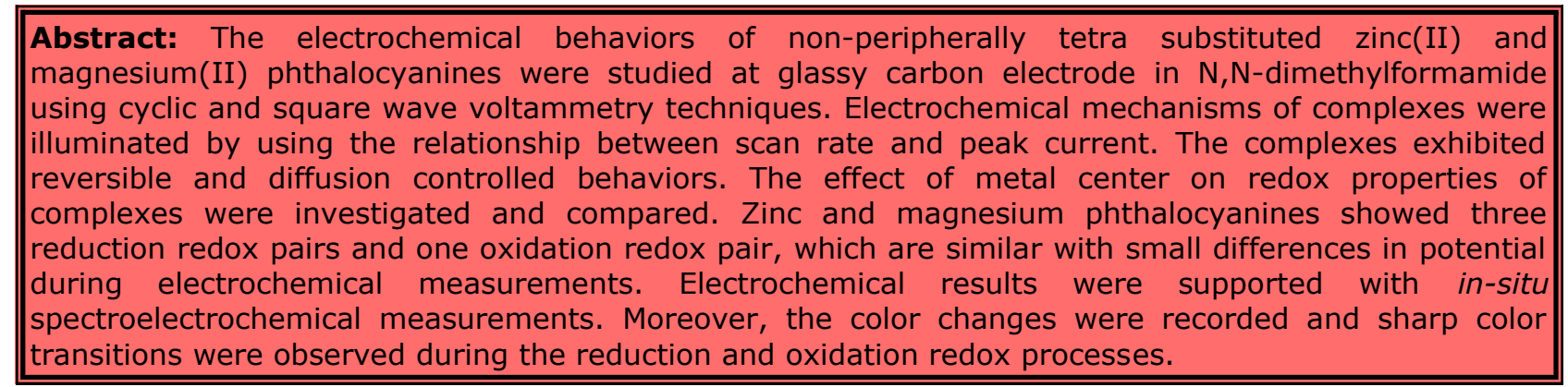

Keywords: Phthalocyanines, electrochemistry, spectroelectrochemistry.

Submitted: August 17, 2020. Accepted: November 03, 2020.

Cite this: Akyüz D. Electrochemical and in-situ spectroelectrochemical behaviors of non-peripherally tetra substituted zinc(II) and magnesium(II) phthalocyanines. JOTCSA. 2021;8(1):9-20.

DOI: https://doi.org/10.18596/jotcsa.781748.

*Corresponding author. E-mail: dakyuz@gtu.edu.tr.

\section{INTRODUCTION}

Phthalocyanines are macrocyclic compounds, which have a large conjugated $18-\Pi$ electron system (1). Numerous properties resulting from electronic delocalization make them valuable in different fields of science and technology (2). The most important advantage of phthalocyanines and metallo-derived phthalocyanines is that they can be modified with various functional groups and their physical, optical and electronic properties can be controlled (3). Metallo-phthalocyanines generally have been used as catalysts $(4,5)$, as organic semiconductors in transistors (6), as photo-active material in laser printers (7), as photosensitizers in dye sensitized solar cells (8) and photodynamic cancer therapy (9).

Recently, triazole substituted phthalocyanine complexes have attracted the attention due to their use in various applications fields such as materials science, agrochemistry, and medicinal chemistry $(10,11)$. We reported previously the synthesis of tetra 4-(4-fluorophenyl)-5-(4methoxyphenyl)-4H-1,2,4-triazole-3-thiol-

substituted non-peripheral metal-free, zinc, lead, and copper phthalocyanines (12). Electrochemical and in-situ spectroelectrochemical responses of the compounds showed reversible and/or quasireversible redox processes and aggregation tendency in $\mathrm{N}, \mathrm{N}$-dimethylformamide. Electrochemical and spectroelectrochemical characterization of compounds are needed for determining redox properties, conductivity, color transition, and electron transfer ability and mechanism. The results of characterization provide information about the potential for use in potential application areas such as electrochromism, sensor, and photodynamic therapy. Although there are many studies on the synthesis and photophysical properties of triazole-substituted phthalocyanine complexes (13-16), there are a few studies about electrochemical and spectroelectrochemical properties of these phthalocyanines in literature $(17,18)$. The non-peripheral 4-(4,5-diphenyl-4H1,2,4-triazol-3-ylthio) substituted $\mathrm{Zn}$ and $\mathrm{Mg}$ 
phthalocyanine complexes were synthesized and photophysical and photochemical properties were reported by our research group (19).

In here, the electrochemical and in-situ spectroelectrochemical properties of synthesized the non-peripheral 4-(4,5-diphenyl-4H-1,2,4triazol-3-ylthio) substituted $\mathrm{Zn}$ and $\mathrm{Mg}$ phthalocyanine complexes were studied for the first time. Redox properties, electron transfer mechanism, reversibility/irreversibility, the effect of metal center were determined by electrochemical characterization. The color transitions during the reduction and oxidation reactions, whether there is a by-product formed during the reaction, whether there is a chemical reaction accompanying the redox reaction, and peak assignments were determined by in-situ spectroelectrochemical measurements.

\section{EXPERIMENTAL SECTION}

The materials and methods for the synthesis of the non-peripheral 4-(4,5-diphenyl-4H-1,2,4-triazol-3ylthio) substituted $\mathrm{Zn}$ and $\mathrm{Mg}$ phthalocyanine complexes were reported in previous study by our research group (19). Briefly, 3-nitrophthalonitrile, potassium carbonate, zinc acetate, and magnesium chloride was purchased from Sigma Aldrich (Darmstadt, Germany). During the synthesis, as solvents such as n-pentanol, 1,8-diazabicyclo [4.5.0] undec-7-ene (DBU), N,Ndimethylformamide (DMF), N,N-dimethylsulfoxide (DMSO), toluene, tetrahydrofuran, ethyl acetate, chloroform, dichloromethane, ethanol, methanol, acetone, 1,3-diphenylisobenzofuran (DPBF) were used and all solvent were purchased from Sigma Aldrich (Darmstadt, Germany).

The synthesized $\mathrm{Zn}$ and $\mathrm{Mg}$ phthalocyanines were characterized by $1 \mathrm{H}-\mathrm{NMR}$ spectra (Varian XL-400 NMR spectrometer), IR spectra (Perkin-Elmer Spectrum One FT-IR spectrometer), MS spectra (BRUKER Microflex LT by MALDI-TOF (Matrix Assisted Laser Desorption Ionization-Time-ofFlight)) and UV-Vis absorption spectra (Perkin Elmer Lambda 25 UV-Vis spectrophotometer). More detailed information has been reported in our previous publication(19).

The electrochemical measurements were carried out via cyclic voltammetry $(\mathrm{CV})$ and square wave voltammetry (SWV) techniques using a potentiostat/galvanostat (Autolab PGSTAT 302N, Metrohm, Istanbul, Turkey). Electrochemical measurements were performed in three-electrode systems consisting of a glassy carbon (GC) electrode (BASi, $3.0 \mathrm{~mm}$ diameter, West Lafayette, USA) as the working electrode, a platinum wire as the counter electrode, and silver-silver chloride (Ag / $\mathrm{AgCl}$ ) as the reference electrode. The tetrabutylammonium perchlorate (TBAP, Merck, Darmstadt, Germany) was used as supporting electrolyte. $5.0 \times 10^{-4} \mathrm{M}$ of the synthesized compounds dissolved in $2.0 \mathrm{~mL}$ dimethylformamide (DMF, Merck, Darmstadt, Germany). Electrochemical measurements were carried out under pure nitrogen gas.

The in-situ spectroelectrochemical experiments were performed in quartz UV-Vis cuvette. A potentiostat/galvanostat (Autolab PGSTAT 302N, Metrohm, Istanbul, Turkey) and a DH-mini UV-VisNIR Light source (Ocean Optics, Florida, USA) with a high-resolution spectrometer (Ocean Optics, Florida, USA) were used as in-situ during the spectroelectrochemical measurements. Pt gauze (working), platinum wire (counter) and $\mathrm{Ag} / \mathrm{AgCl}$ electrode (reference) were used. All of measurements were performed in DMF/TBAP electrolyte system under nitrogen atmosphere.

\section{RESULT AND DISCUSSIONS}

\section{Synthesis}

The synthesis procedures of the non-peripheral 4(4,5-diphenyl-4H-1,2,4-triazol-3-ylthio) substitute zinc and magnesium phthalocyanines were reported by our research group (19). Briefly, for the synthesis of $\mathrm{Zn}$ and $\mathrm{Mg}$ phthalocyanine compounds, $0.4 \mathrm{~g}$ of $1.05 \mathrm{mmol}$ of phthalonitrile was placed in a flask in the presence of $5 \mathrm{~mL}$ of $\mathrm{n}$ pentanol. Then, 5 drops of DBU were added as catalyst. Finally, an equivalent amount of anhydrous metal salt $\mathrm{Zn}\left(\mathrm{CH}_{3} \mathrm{COO}\right)_{2}$ for $\mathrm{ZnPc}, \mathrm{MgCl}_{2}$ salt for $\mathrm{MgPc}$ was added. The reaction was continued at $160{ }^{\circ} \mathrm{C}$ for 24 hours and then the cooled mixture was poured into n-hexane. The crude solid product was refined by column chromatography after washing with ethanol, ethyl acetate and acetone. Figure 1 shows the structure of the synthesized non-peripherally tetra substituted zinc(II) and magnesium(II) phthalocyanines. 


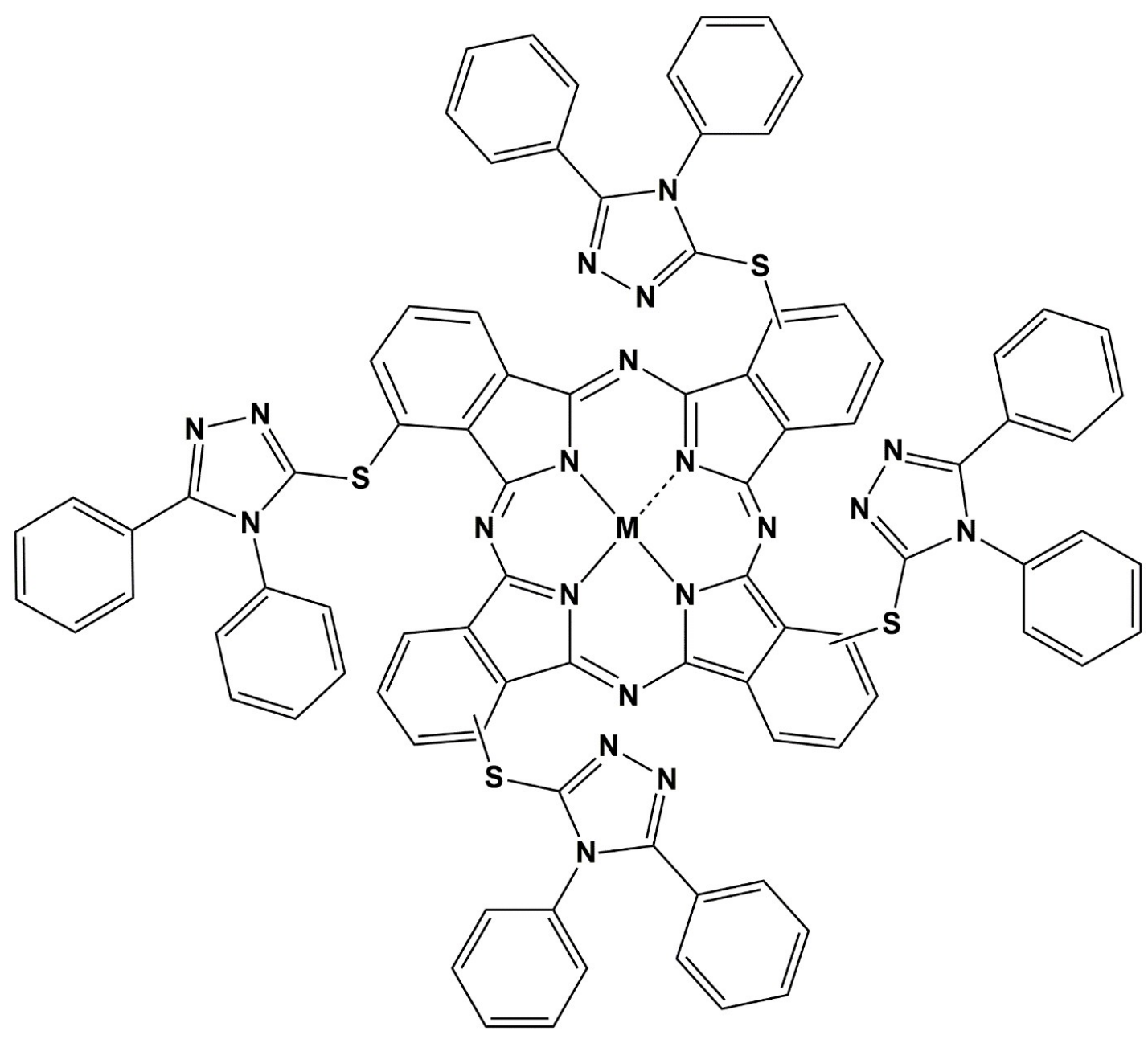

\section{$\mathrm{M}=\mathrm{Zn}, \mathbf{M g}$}

Figure 1. The schematic representation of the non-peripheral 4-(4,5-diphenyl-4H-1,2,4-triazol-3-ylthio) substituted zinc and magnesium phthalocyanines (19).

\section{Electrochemical spectroelectrochemical measurements} $\mathrm{ZnPC}$

The electrochemical data of synthesized compounds ( $\mathrm{ZnPc}$ and $\mathrm{MgPc}$ ) were performed by $\mathrm{CV}$ and SWV measurements in DMF/TBAP electrolyte system. The peak to peak separation $\left(\Delta E_{\mathrm{p}}\right)$, half-wave potential $\left(E_{1 / 2}\right)$, the ratio of anodic to cathodic peak currents of redox couples $\left(I_{\mathrm{p}, \mathrm{a}}\right)$ $I_{\mathrm{p}, \mathrm{c}}$ ) of each wave and separation of half-wave potential $\left(\Delta E_{1 / 2}\right)$ for HOMO-LUMO gap value and were determined from plot of $\mathrm{CV}$ and SWV. The electrochemical data were given in Table 1 . It is well known that the redox waves are associated with the metal atom at the center and the substituent of the compound (20). Therefore, the effect of metal center and substituent of phthalocyanine were investigated on electrochemical and spectroelectrochemical properties. It was reported that phthalocyanines having redox inactive metal center $\left(\mathrm{Ni}^{2+}, \mathrm{Zn}^{2+}\right.$, $\mathrm{Cu}^{2+}, \mathrm{Mg}^{2+}$ ) generally show four redox couples, three reduction couples and one oxidation couple depending on the potential limit of the solvent being studied $(12,21,22)$. Metal-free phthalocyanine complexes generally show reduction couples at $-0.63,-1.05$ and $-1.38 \mathrm{~V}$ and approximately at $0.86 \mathrm{~V}$ oxidation couple in DMF electrolyte solution $(23,24)$. The electrochemical responses of $\mathrm{ZnPc}$ were showed in Figure 2. ZnPc exhibited three reduction couples at $-0.67,-1.08$ and $-1.77 \mathrm{~V}$ and one oxidation couple at $0.81 \mathrm{~V}$ and data are also tabulated in Table 1 . The phthalocyanine ring of $\left[\mathrm{Zn}^{\mathrm{II}} \mathrm{Pc}^{-2}\right]$ was first reduced to $\left[\mathrm{Zn}^{\mathrm{II}} \mathrm{Pc}^{-3}\right]^{-}$during the cathodic potential scan labeled as $\mathrm{R}_{\mathrm{I}}$, as seen in Figure $2 \mathrm{a}$. The secondly, $\left[\mathrm{Zn}^{\mathrm{II}} \mathrm{Pc}^{-3}\right]^{-}$species in the electrolyte was reduced to $\left[\mathrm{Zn}^{\mathrm{II}} \mathrm{Pc}^{-4}\right]^{2-}$ at more negative voltage labeled as $\mathrm{R}_{\mathrm{II}}$. Finally, the $\left[\mathrm{Zn}^{\mathrm{II}} \mathrm{Pc}^{-4}\right]^{2-}$ species reduced to $\left[\mathrm{Zn}^{\mathrm{II}} \mathrm{Pc}^{-}\right.$ $\left.{ }^{5}\right]^{3-}$ species as labelled $\mathrm{R}_{\mathrm{III}}$. During the oxidation reaction, $\mathrm{ZnPc}$ oxidized to $\left[\mathrm{Zn}^{\mathrm{II}} \mathrm{Pc}^{-1}\right]^{+}$species as labelled $\mathrm{O}_{\text {I. }}$. When $\mathrm{ZnPc}$ was compared to with other triazole substituted zinc phthalocyanines in the literature, it showed more positive reduction potential to literature (24-26). This result can be stemmed from electron-releasing character of 4(4,5-diphenyl-4H-1,2,4-triazol-3-ylthio)

substituent. It is well known that while more electron-donating substituents make more difficult reduction process and more easy oxidation 
process, more electron-releasing substituents make more easy reduction process and more difficult oxidation process (27). $\Delta E_{\mathrm{p}}$ values was calculated using a formula $\Delta E_{\mathrm{p}}=E_{\mathrm{pa}}-E_{\mathrm{pc}}=0.0592 / \mathrm{n}$ $\mathrm{V}$, which is the criterion of theoretical reversibility (28). $\Delta E_{\mathrm{p}}$ values of $\mathrm{ZnPc}$ was obtained $\mathrm{CV}$ voltammogram at $100 \mathrm{mV} / \mathrm{s}$ and reduction and oxidation process indicated reversible character. The $E_{1 / 2}$ and $E_{\mathrm{p}}$ values of $\mathrm{ZnPc}$ are in agreement with literature as seen in Table $1 . I_{\mathrm{pa}} / I_{\mathrm{pc}} \approx 1$ showed that the electrode reaction was not accompanied by chemical reactions and it carried out as a result of electrochemical reactions. SWV technique provides high sensitivity and reliable data at low concentration. SWV measurements of $\mathrm{ZnPc}$ was indicated in Figure $2 \mathrm{~b}$ and SWV results supported CV data. The cyclic voltammograms were obtained at various scan rates from 25 to $1000 \mathrm{mV} / \mathrm{s}$ as shown in Figure 2a.
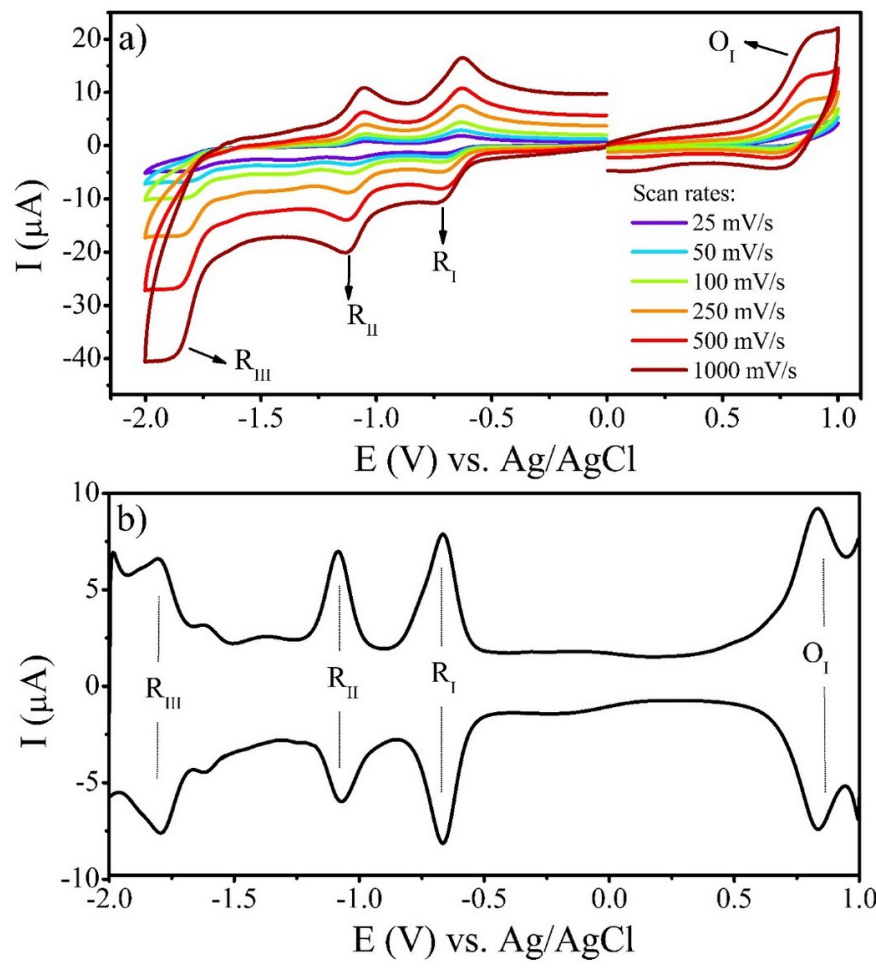

Figure 2. a) Cyclic voltammogram of ZnPc on GCE in DMF/TBAP at various scan rates b) The SWV voltammogram of the complex.

Scan rate studies have been carried out to determine whether the electron transfer is diffusion-controlled on GCE. The square root of scan rate versus the peak current for each redox couples was plotted and a linear line was obtained in the range of $0.025-0.25 \mathrm{mVs}^{-1}$ as shown in Figure 3. It was reported that $I_{\mathrm{p}} / \mathrm{v}^{1 / 2}$ must be constant in diffusion-controlled process $(28,29)$. This linear relationship shows that the redox reactions of $\mathrm{ZnPc}$ are diffusion-controlled. According to electrochemical results of $\mathrm{ZnPc}$, proposed electron transfer mechanism is as the follows:

Oxidation reaction: $\left[\mathrm{Zn}^{\mathrm{II}} \mathrm{Pc}^{2-}\right] \leftrightarrows\left[\mathrm{Zn}^{\mathrm{II}} \mathrm{Pc}^{-}\right]+\mathrm{e}^{-}(1)$
Reduction reactions:

$$
\begin{aligned}
& {\left[\mathrm{Zn}^{\mathrm{II}} \mathrm{Pc}^{2-}\right]+\mathrm{e}^{-} \leftrightarrows\left[\mathrm{Zn}^{\mathrm{II}} \mathrm{Pc}^{3-}\right]^{-}} \\
& {\left[\mathrm{Zn}^{\mathrm{II}} \mathrm{Pc}^{3-}\right]^{-}+\mathrm{e}^{-} \leftrightarrows\left[\mathrm{Zn}^{\mathrm{II}} \mathrm{Pc}^{4-}\right]^{2-}} \\
& {\left[\mathrm{Zn}^{\mathrm{II}} \mathrm{Pc}^{4-}\right]^{2-}+\mathrm{e}^{-} \leftrightarrows\left[\mathrm{Zn}^{\mathrm{II}} \mathrm{Pc}^{5-}\right]^{3-}}
\end{aligned}
$$

The proposed oxidation mechanism (Equation 1) can be assigned to $\left[\mathrm{Zn}^{\mathrm{II}} \mathrm{Pc}^{-2}\right] /\left[\mathrm{Zn}^{\mathrm{II}} \mathrm{Pc}^{-1}\right]^{+}$redox couple labelled as $\mathrm{O}_{\mathrm{I}}$ in Figure $2 \mathrm{a}$ and $\mathrm{b}$. Reduction reactions can be assigned to $\left[\mathrm{Zn}^{I I} \mathrm{Pc}^{-2}\right] /\left[\mathrm{Zn}^{\mathrm{II}} \mathrm{Pc}^{-3}\right]^{-}$ as $\mathrm{R}_{\mathrm{I}}$ (Equation 2), $\left[\mathrm{Zn}^{\mathrm{II}} \mathrm{Pc}^{-3}\right]^{-} /\left[\mathrm{Zn}^{\mathrm{II}} \mathrm{Pc}^{-4}\right]^{2-}$ as $\mathrm{R}_{\mathrm{II}}$ (Equation 3) and $\left[\mathrm{Zn}^{\mathrm{II}} \mathrm{Pc}^{-4}\right]^{2-} /\left[\mathrm{Zn}^{\mathrm{II}} \mathrm{Pc}^{-5}\right]^{3-}$ redox couple as $\mathrm{R}_{\mathrm{III}}$ (Equation 4). These assignments are in agreement with literature (30). 


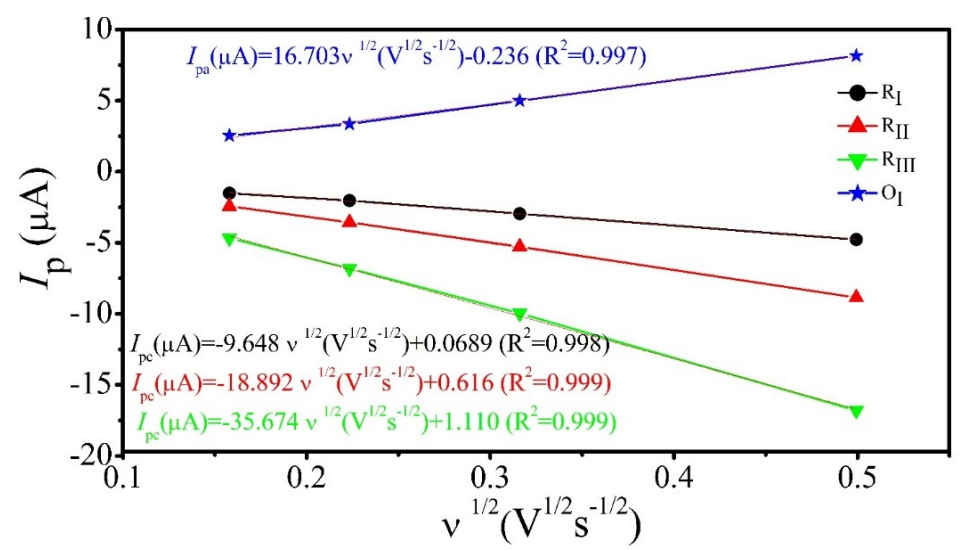

Figure 3. Dependence of anodic peak currents for oxidation, cathodic peak currents for reduction on the square root of scan rate for $\mathrm{ZnPc}$.

In-situ spectroelectrochemical measurements were performed to illuminate the presence of intermediates formed during the reaction, chemical reactions or impurities accompanying the redox reactions, aggregation formation, color change, and assignment of redox couples. Figure 4 represents in-situ spectroelectrochemical measurements of ZnPc. During the first reduction process, the intensity of $\mathrm{Q}$ band, which is characteristic for phthalocyanines, at $700 \mathrm{~nm}$ with small shoulder at $631 \mathrm{~nm}$ decreases and new bands appears at 601 and $661 \mathrm{~nm}$ during constant potential electrolysis at $-0.75 \mathrm{~V}$. Decrease in the intensity of the $\mathrm{Q}$ band without any shifting and appearance of a peak in charge transfer region shows the characteristic ring based reduction process (31-33). This spectroelectrochemical changes support that $\left[\mathrm{Zn}^{\mathrm{II}} \mathrm{Pc}^{-3}\right]^{-}$occurs by a onestep electrode reaction as shown in Equation 1. Then, when applied more negative potential $(-1.25$ $\mathrm{V})$, second electron transfer performed based on ligand reduction (Figure $4 \mathrm{~b}$ ). The intensity of the bands at 661 and $700 \mathrm{~nm}$ decreased and new bands at 552 and $586 \mathrm{~nm}$ appeared. Generally, it is difficult to observe the spectral changes of the third electron transfer. Figure $4 \mathrm{c}$ shows the spectral changes during the oxidation process. The intensity of the $\mathrm{Q}$ band decreased without shifting at $1.00 \mathrm{~V}$. This change is a characteristic behavior for ligand-based oxidation reactions (33). Color changes of the $\mathrm{ZnPc}$ was recorded with in-situ electrocolorimetric measurements (Figure 4d). Before the reduction/oxidation reactions, the color of $\mathrm{ZnPc}$ is greenish blue $(x=0.3213, y=0.3525)$.
During the reduction process, the color turns to light blue $(x=0.3012, y=0.3364)$, which shows the presence of $\left[\mathrm{Zn}^{\mathrm{II}} \mathrm{Pc}^{-3}\right]^{-}$species and then blue color $(x=0.3065, y=0.3028)$, which indicates presence of $\left[\mathrm{Zn}^{\mathrm{II}} \mathrm{Pc}^{-4}\right]^{2-}$ species in solution. The color of $\mathrm{ZnPc}$ did not change much during the oxidation reaction $(x=0.3336, y=0.3458)$.

\section{$M g P C$}

Figure 5 illustrates the electrochemical response of MgPc. MgPc exhibited similar electrochemical behavior with slight differences from that of ZnPc. These differences can stem from position of metal center. $\mathrm{MgPc}$ indicates three reversible reduction couples at $E_{1 / 2}=-0.69 \mathrm{~V},-1.17 \mathrm{~V}$ and $-1.87 \mathrm{~V}$, respectively and one reversible oxidation couple at $E_{1 / 2}=0.80 \mathrm{~V}$. The redox couple labeled $\mathrm{R}_{\mathrm{I}}$ in the Figure $5 \mathrm{a}$ and $\mathrm{b}$ corresponds to the ring reduction

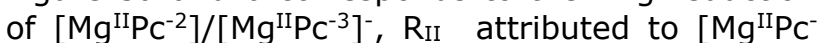
$\left.{ }^{3}\right]^{-} /\left[\mathrm{Mg}^{\mathrm{II}} \mathrm{Pc}^{-4}\right]^{2-}, \mathrm{R}_{\mathrm{III}}$ attributed to $\left[\mathrm{Mg}^{\mathrm{II}} \mathrm{PC}^{-}\right.$ $\left.{ }^{4}\right]^{2-} /\left[\mathrm{Mg}^{\mathrm{II}} \mathrm{Pc}^{-5}\right]^{3-}$ and $\mathrm{O}_{\mathrm{I}}$ attributed to ring oxidation of $\left[\mathrm{Mg}^{\mathrm{II}} \mathrm{Pc}^{-2}\right] /\left[\mathrm{Mg}^{\mathrm{II}} \mathrm{Pc}^{-1}\right]^{+}$. Electrochemical data are given in Table 1 . As shown in Figure 6, the peak current of the reduction and oxidation peaks is directly proportional to the square root of the scan rate. Therefore, the electrochemical reactions of $\mathrm{MgPc}$ performed as diffusion-controlled in the result of one-electron transfer. When the Table 1 is examined, $\mathrm{MgPc}$ is reduced at a more negative potential and is more easily oxidized than ZnPc. This difference can be stemmed from the effective nuclear charge differences between the magnesium and zinc metal centers in the phthalocyanine ring and radius of metal center. 


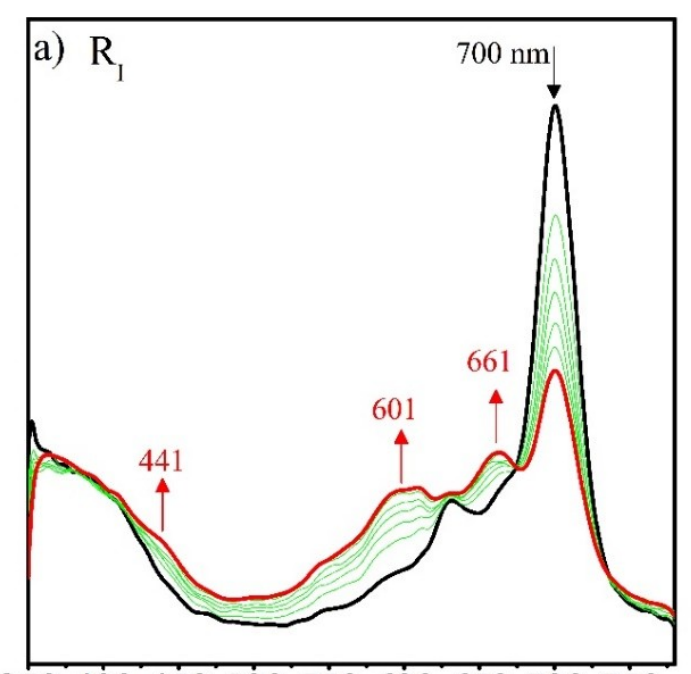

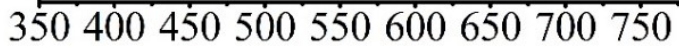

Wavelength (nm)

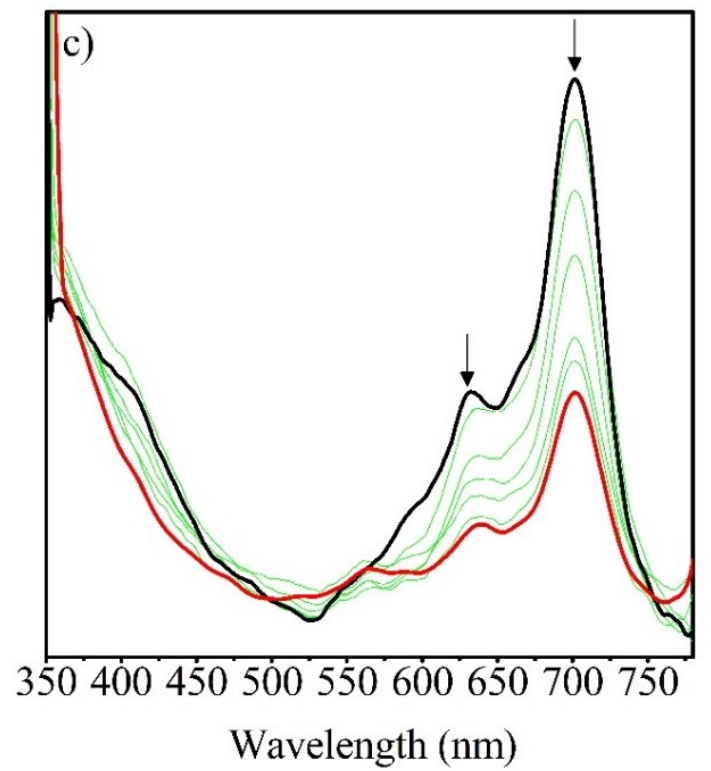

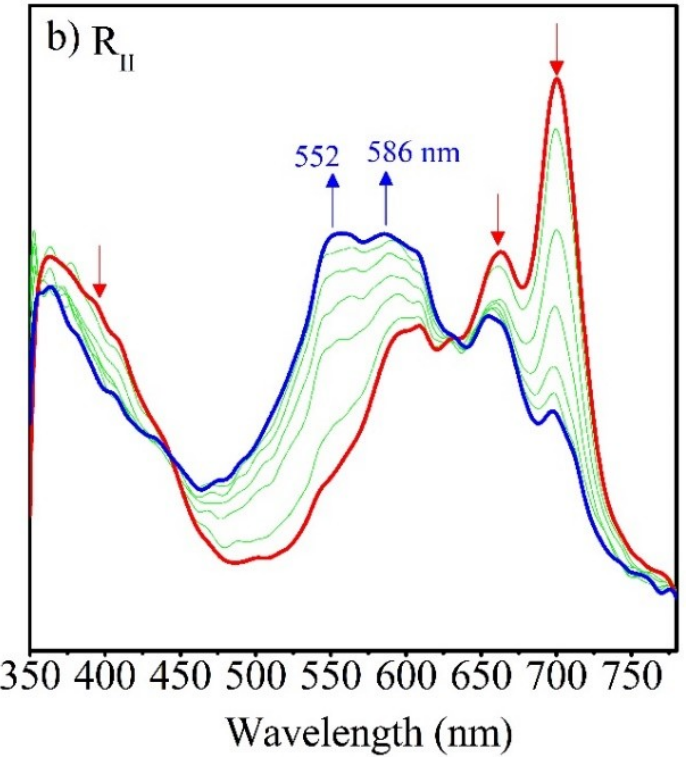

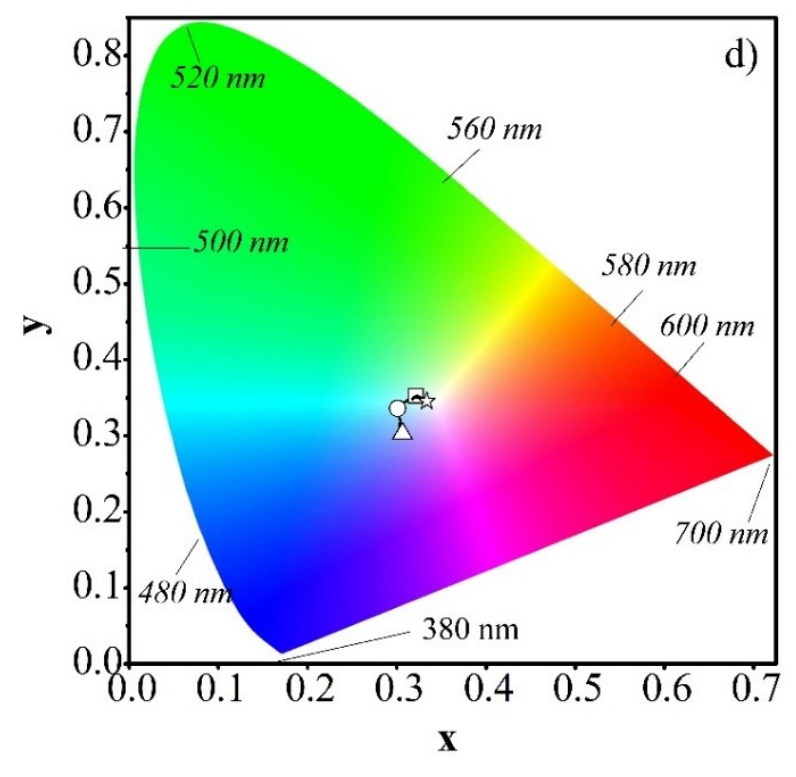

Figure 4. The in-situ spectroelectrochemical measurements of $\mathrm{ZnPc}$ a) during the first reduction reaction at $-0.75 \mathrm{~V}, \mathbf{b}$ ) during the second reduction reaction at $-1.25 \mathrm{~V}, \mathbf{c}$ ) during the oxidation reaction at $1.00 \mathrm{~V}$, d) The symbols represent the color of occurred species in chromaticity diagram $\quad{ }^{\circ}:\left[\mathrm{Zn}^{\mathrm{II}} \mathrm{Pc}^{-2}\right]$;

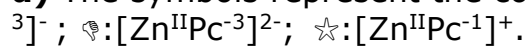



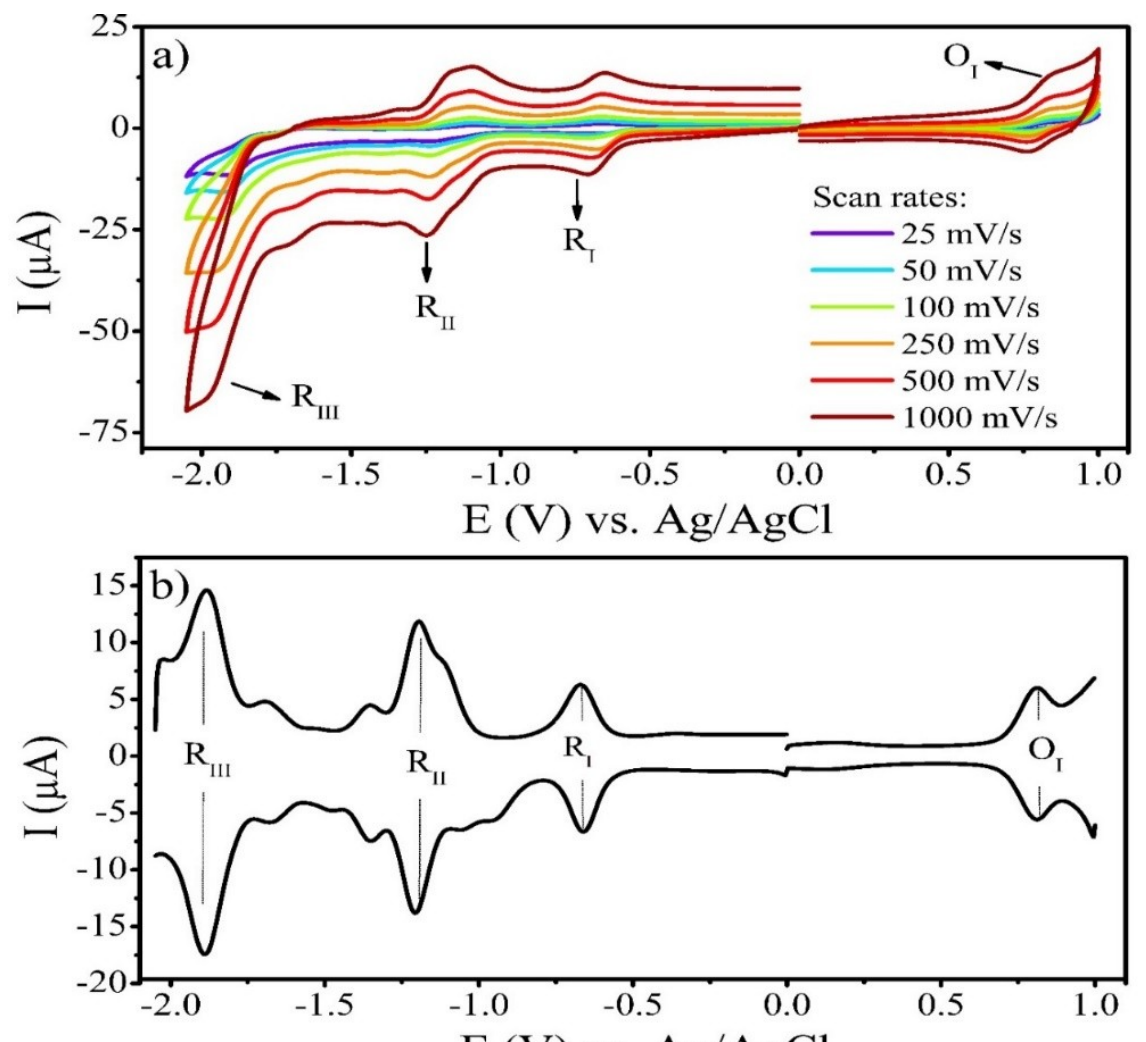

$\mathrm{E}(\mathrm{V})$ vs. Ag/AgCl

Figure 5. a) The cyclic voltammogram of MgPc on GCE in DMF/TBAP at various scan rates b) The SWV voltammogram.

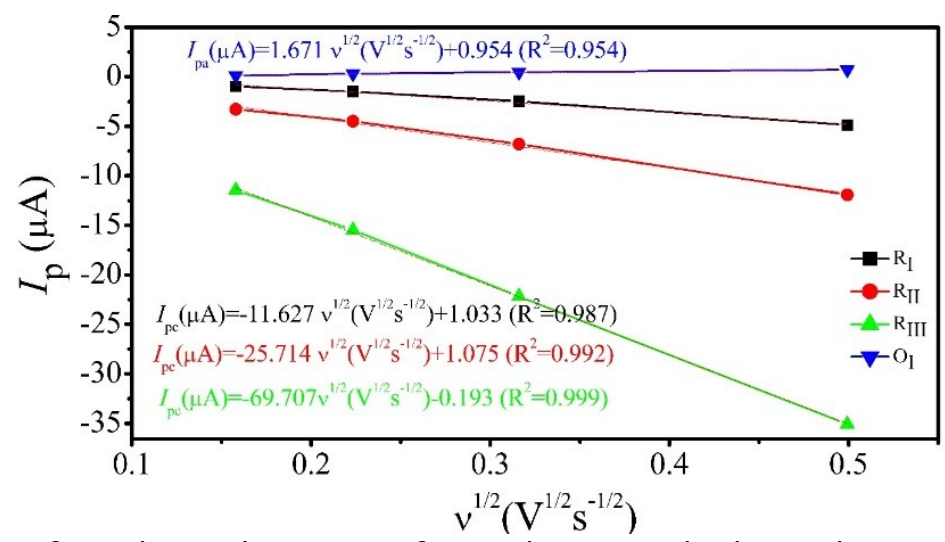

Figure 6. Dependence of anodic peak currents for oxidation, cathodic peak currents for reduction on the square root of scan rate for MgPc.

As a result of the electrochemical characterizations of $\mathrm{MgPc}$ in Figure 5, a typical ring-based reaction mechanism was proposed as follows:

Oxidation reaction: $\left[\mathrm{Mg}^{\mathrm{II}} \mathrm{Pc}^{2-}\right] \leftrightarrows\left[\mathrm{Mg}^{\mathrm{II}} \mathrm{Pc}^{-}\right]^{+}+\mathrm{e}^{-}(5)$

Reduction reactions:

$$
\begin{aligned}
& {\left[\mathrm{Mg}^{\mathrm{II}} \mathrm{Pc}^{2-}\right]+\mathrm{e}^{-} \leftrightarrows\left[\mathrm{Mg}^{\mathrm{II}} \mathrm{Pc}^{-3}\right]} \\
& {\left[\mathrm{Mg}^{\mathrm{II}} \mathrm{Pc}^{3-}\right]^{-}+\mathrm{e}^{-} \leftrightarrows\left[\mathrm{Mg}^{\mathrm{II}} \mathrm{Pc}^{4-}\right]^{2-}} \\
& {\left[\mathrm{Mg}^{\mathrm{II}} \mathrm{Pc}^{4-}\right]^{2^{-}}+\mathrm{e}^{-} \leftrightarrows\left[\mathrm{Mg}^{\mathrm{II}} \mathrm{Pc}^{5-}\right]^{3-}}
\end{aligned}
$$

Spectroelectrochemical measurements of MgPc were recorded during electrochemical reduction and oxidation reactions (Figure 7). The $\mathrm{Q}$ band of MgPc complex observed at $703 \mathrm{~nm}$ with a small shoulder at $631 \mathrm{~nm}$. The intensity of characteristic $\mathrm{Q}$ band reduced without shifting and a new band appeared in the range of $530-620 \mathrm{~nm}$ at $-0.90 \mathrm{~V}$ constant potential (Figure 7a). Figure 7a can be assigned to Equation 6. During the second reduction, the $\mathrm{Q}$ band disappeared and new peak increased at $548 \mathrm{~nm}$ under potential of $-1.50 \mathrm{~V}$ (Figure 7b). Figure 7b can be assign to Equation 7. These spectral changes occurring without shift are characteristic for phthalocyanine ring reduction and thus the formation of $\mathrm{Mg}^{\mathrm{II} \mathrm{Pc}^{-4}}$ species, corresponding to the redox couple in the CV labeled with $\mathrm{R}_{\mathrm{II}}(31,32,34)$. The oxidation process was carried out with electrolysis of solutions including $\mathrm{MgPc}$ at $1.00 \mathrm{~V}$ constant potential (Figure 7c). The intensity of the $Q$ band decreased, which can be assigned to Equation 5 . The color changes in relation to the occurred redox species during the 
redox reactions were recorded in Figure $7 \mathrm{~d}$. The light blue color $(x=0.3156, y=0.3487)$ of $\mathrm{MgPc}$ at zero voltage turns to blue $(x=0.3162, y=0.3291)$ and then the color does not change $(x=0.3167$,
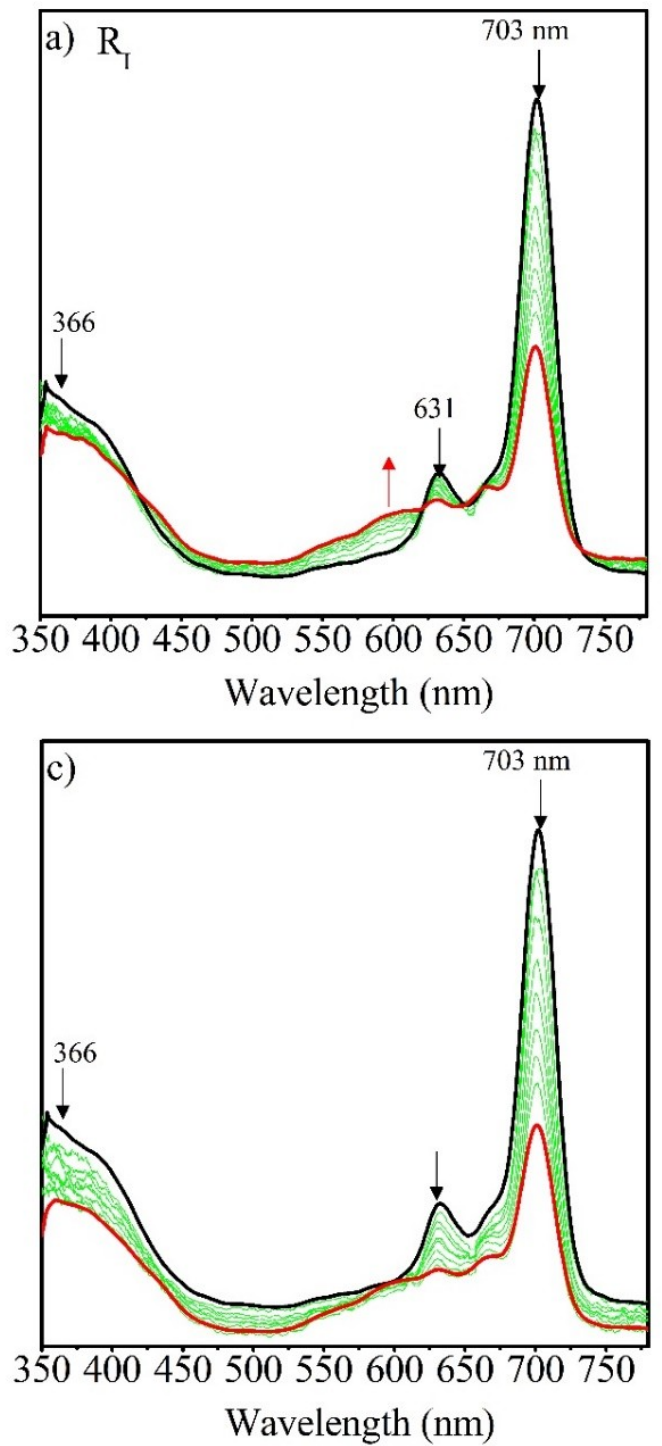

$y=0.3009$ ) during the reduction process, respectively. The light blue color of $\mathrm{MgPc}$ turns to greenish blue $(x=0.3333, y=0.3602)$ during the oxidation process.
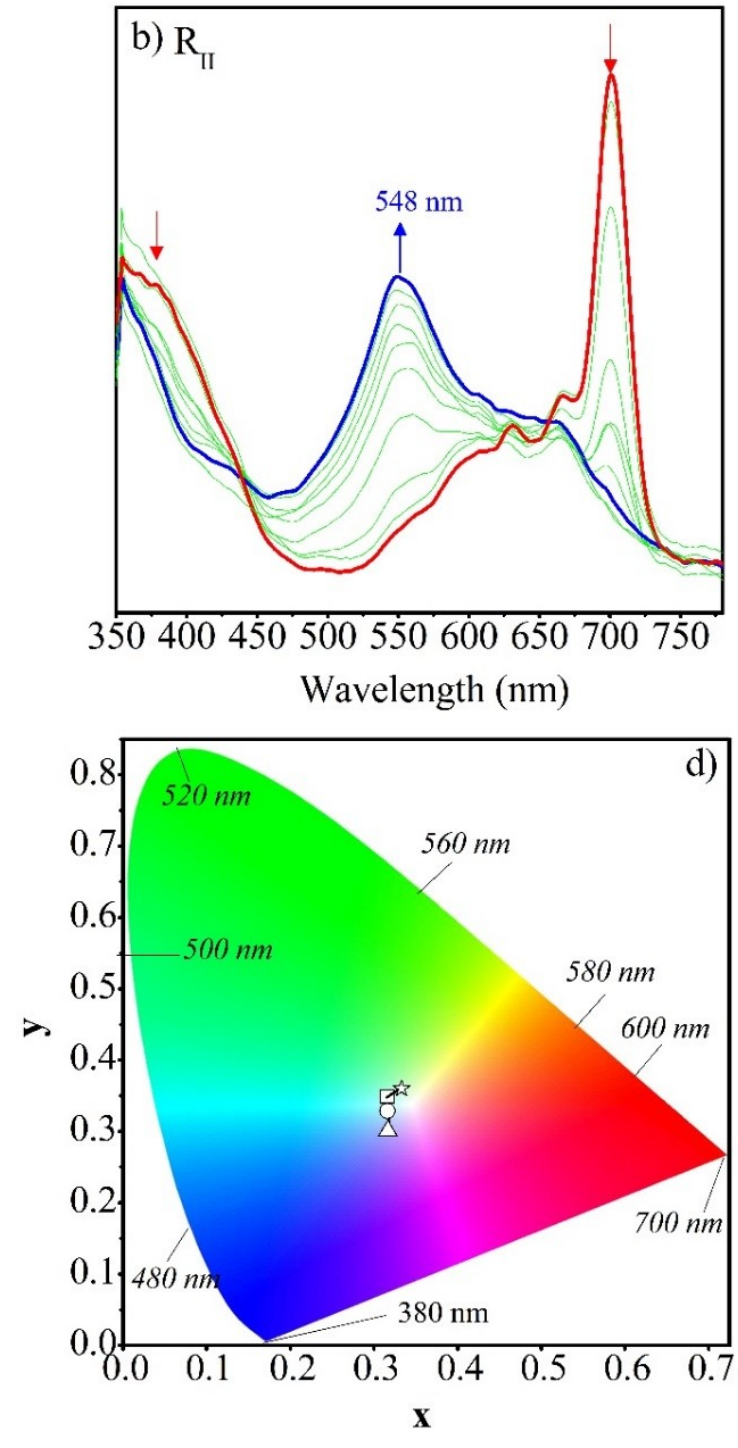

Figure 7. The in-situ spectroelectrochemical measurements of $\mathrm{MgPc}$ a) during the first reduction reaction at $-0.90 \mathrm{~V}, \mathbf{b})$ during the second reduction reaction at $-1.50 \mathrm{~V}, \mathbf{c}$ ) during the oxidation reaction at $1.00 \mathrm{~V}$, d) The symbols represent the color of occurred species in chromaticity diagram $\square:\left[\mathrm{Mg}^{\mathrm{II}} \mathrm{Pc}^{-2}\right] ; 0:\left[\mathrm{Mg}^{\mathrm{II}} \mathrm{Pc}^{-}\right.$ $\left.{ }^{3}\right]^{-} ; \Delta:\left[\mathrm{Mg}^{\mathrm{II}} \mathrm{Pc}^{-4}\right]^{2-} ;$ is: $\left[\mathrm{Mg}^{\mathrm{II}} \mathrm{Pc}^{-1}\right]^{+}$.

\section{CONCLUSION}

The non-peripheral 4-(4,5-diphenyl-4H-1,2,4triazol-3-ylthio) substituted $\mathrm{Zn}$ and $\mathrm{Mg}$ phthalocyanine complexes were characterized for the first time by electrochemical and in-situ spectroelectrochemical measurements. The electrochemical parameters such as $E_{1 / 2}, \Delta E_{p}, I_{\mathrm{p}, \mathrm{a}}$ $I_{\mathrm{p}, \mathrm{c}}$ and $\Delta E_{1 / 2}$ determined and tabulated. Complexes showed electrochemically reversible behavior in DMF/TBAP electrolyte system. The electrochemical responses of $\mathrm{ZnPc}$ and $\mathrm{MgPc}$ are similar with small difference in reduction and oxidation potentials. The peak assignments of complexes and electron transfer mechanism was illuminated and reaction mechanisms were purposed. Electrochemical responses are also supported in-situ spectroelectrochemical measurements. The effect of 4-(4,5-diphenyl-4H1,2,4-triazol-3-ylthio) substituents of compounds on electrochemical responses was investigated. The non-peripheral 4- (4,5-diphenyl-4H-1,2,4triazol-3-ylthio) substitution of the compounds with respect to other triazoles in the literature facilitated electrochemical reduction reactions. Electrochemical and in-situ spectroelectrochemical studies reveal that ligand based redox couples are generated during the in-situ electrolysis of the zinc and magnesium phthalocyanines. These compounds may have potential application due to rich redox properties as dual sensitizers in the photodynamic therapy and solar cell. 
Table 1. The electrochemical data MgPc and ZnPc complexes and a brief summary of summary of triazole including phthalocyanine complexes the literature.

\begin{tabular}{ccccccc}
\hline Compound & & $\boldsymbol{E}_{\mathbf{1 / 2}}$ & $\boldsymbol{\Delta \boldsymbol { e } _ { \boldsymbol { p } } ( \mathbf { m V } )}$ & $\boldsymbol{I}_{\mathbf{p}, \mathbf{a}} / \boldsymbol{I}_{\mathbf{p}, \mathbf{c}}$ & $\boldsymbol{\Delta E}_{\mathbf{1} / \mathbf{2}}$ & References \\
\hline & $\mathrm{R}_{\mathrm{I}}$ & -0.67 & 71 & 1.10 & & This work \\
(in DMP & $\mathrm{R}_{\mathrm{II}}$ & -1.08 & 60 & 1.02 & 1.48 & \\
& $\mathrm{R}_{\mathrm{III}}$ & -1.77 & 80 & 0.88 & & \\
& $\mathrm{O}_{\mathrm{I}}$ & 0.81 & 83 & 0.79 & & This work \\
MgPc & $\mathrm{R}_{\mathrm{I}}$ & -0.69 & 60 & 0.99 & & \\
(in DMF) & $\mathrm{R}_{\mathrm{II}}$ & -1.17 & 85 & 0.81 & 1.49 & \\
& $\mathrm{R}_{\mathrm{III}}$ & -1.87 & 80 & 0.75 & & \\
& $\mathrm{O}_{\mathrm{I}}$ & 0.80 & 60 & 0.70 & & \\
\hline
\end{tabular}

\begin{tabular}{|c|c|c|c|c|c|c|}
\hline & & & & & & \\
\hline $\begin{array}{c}\mathrm{H}_{2} \mathrm{Pc} \\
\text { (in DMF) }\end{array}$ & $\begin{array}{c}\mathrm{R}_{\mathrm{I}} \\
\mathrm{R}_{\mathrm{II}} \\
\mathrm{R}_{\mathrm{III}} \\
\mathrm{O}_{\mathrm{I}}\end{array}$ & $\begin{array}{c}-0.63 \\
-1.05 \\
-1.38 \\
0.86\end{array}$ & $\begin{array}{l}- \\
- \\
- \\
-\end{array}$ & $\begin{array}{l}- \\
- \\
- \\
-\end{array}$ & - & (23) \\
\hline $\begin{array}{c}\mathrm{H}_{2} \mathrm{Pc} \\
\text { (in DMSO) }\end{array}$ & $\begin{array}{c}\mathrm{R}_{\mathrm{I}} \\
\mathrm{R}_{\mathrm{II}} \\
\mathrm{R}_{\mathrm{III}} \\
\mathrm{O}_{\mathrm{I}}\end{array}$ & $\begin{array}{c}-0.52 \\
-0.97 \\
-1.80 \\
- \\
\end{array}$ & $\begin{array}{c}74 \\
72 \\
66 \\
- \\
\end{array}$ & $\begin{array}{l}- \\
- \\
- \\
-\end{array}$ & - & (35) \\
\hline $\begin{array}{c}\text { ZnPc } \\
\text { (in DMF) }\end{array}$ & $\begin{array}{c}\mathrm{R}_{\mathrm{I}} \\
\mathrm{R}_{\mathrm{II}} \\
\mathrm{R}_{\mathrm{III}} \\
\mathrm{O}_{\mathrm{I}}\end{array}$ & $\begin{array}{c}-0.84 \\
-1.35 \\
- \\
0.64\end{array}$ & $\begin{array}{c}60 \\
60 \\
- \\
80\end{array}$ & $\begin{array}{c}0.97 \\
0.66 \\
- \\
0.62\end{array}$ & 1.54 & (36) \\
\hline $\begin{array}{c}\text { ZnPc } \\
\text { (in DMSO) }\end{array}$ & $\begin{array}{c}\mathrm{R}_{\mathrm{I}} \\
\mathrm{R}_{\mathrm{II}} \\
\mathrm{R}_{\mathrm{III}} \\
\mathrm{O}_{\mathrm{I}}\end{array}$ & $\begin{array}{c}-0.82 \\
-1.26 \\
-1.86 \\
0.62\end{array}$ & $\begin{array}{l}60 \\
63 \\
80 \\
87 \\
\end{array}$ & $\begin{array}{l}1.00 \\
1.06 \\
0.30 \\
0.86 \\
\end{array}$ & - & (26) \\
\hline $\begin{array}{c}\text { MgPc } \\
\text { (in DCM) }\end{array}$ & $\begin{array}{c}\mathrm{R}_{\mathrm{I}} \\
\mathrm{R}_{\mathrm{II}} \\
\mathrm{O}_{\mathrm{I}} \\
\mathrm{O}_{\mathrm{II}}\end{array}$ & $\begin{array}{c}-1.70 \\
-2.17 \\
0.09 \\
0.63\end{array}$ & $\begin{array}{c}61 \\
78 \\
136 \\
80\end{array}$ & $\begin{array}{l}- \\
- \\
- \\
-\end{array}$ & - & (37) \\
\hline $\begin{array}{c}\text { MgPc } \\
\text { (in DMF) }\end{array}$ & $\begin{array}{c}\mathrm{R}_{\mathrm{I}} \\
\mathrm{R}_{\mathrm{II}} \\
\mathrm{O}_{\mathrm{I}}\end{array}$ & $\begin{array}{c}-0.90 \\
-1.39 \\
0.65\end{array}$ & $\begin{array}{l}- \\
- \\
-\end{array}$ & $\begin{array}{l}- \\
- \\
-\end{array}$ & 1.55 & (34) \\
\hline
\end{tabular}

$E_{1 / 2}$ values $\left(\left(E_{\text {anodic peak }}+E_{\text {cathodic peak }}\right) / 2\right), \Delta E_{p}=E_{\text {anodic peak }}-E_{\text {cathodic peak }}=E_{\mathrm{pa}}-E_{\mathrm{pc}}$ and $I_{\mathrm{pa}} / I_{\mathrm{pc}}$ is the rate of peak currents. $\Delta E_{1 / 2}=E_{1 / 2}$ (the first oxidation) $-E_{1 / 2}$ (the first reduction).

\section{REFERENCES}

1. Lever AP. The phthalocyanines. Advances in Inorganic Chemistry and Radiochemistry. 7: Elsevier; 1965. p. 27-114.

2. de la Torre G, Claessens CG, Torres T. Phthalocyanines: old dyes, new materials. Putting color in nanotechnology. Chemical communications. 2007(20):2000-15.

3. Claessens CG, Hahn $U$, Torres $T$. Phthalocyanines: From outstanding electronic properties to emerging applications. The Chemical Record. 2008;8(2):75-97.

4. Akyüz $D$, Dinçer $H$, Özkaya $A R$, Koca $A$. Electrocatalytic hydrogen evolution reaction with metallophthalocyanines modified with click electrochemistry. International Journal of Hydrogen Energy. 2015;40(38):12973-84.

5. Özçeşmeci İ, Demir A, Akyüz D, Koca A, Gül A. Electrocatalytic hydrogen evolution reaction with a supramolecular cobalt(II) phthalocyanine carrying four cobaloxime moieties. Inorganica Chimica Acta. 2017;466:591-8.
6. Zhang $Y$, Cai $X$, Bian $Y$, Jiang J. Organic semiconductors of phthalocyanine compounds for field effect transistors (FETs). Functional Phthalocyanine Molecular Materials: Springer; 2010. p. 275-321.

7. Döring $S$, Otto $T$, Cehovski $M$, Charfi O, Caspary R, Kowalsky W, et al. Highly sensitive wide range organic photodiode based on zinc phthalocyanine: C60. physica status solidi (a). 2016;213(9):2387-91.

8. Yıldız B, Güzel E, Akyüz D, Arslan BS, Koca A, Şener MK. Unsymmetrically pyrazole-3carboxylic acid substituted phthalocyanine-based photoanodes for use in water splitting photoelectrochemical and dye-sensitized solar cells. Solar Energy. 2019;191:654-62.

9. Aliosman $M$, Angelov I, Mitrev $Y$, Iliev I, Durmuş $M$, Mantareva $V$. Novel $\mathrm{Zn}$ (II) phthalocyanine with tyrosine moieties for photodynamic therapy: Synthesis and comparative study of light-associated properties. Polyhedron. 2019;162:121-8. 
10. Kaya M, Menteşe E, Sökmen BB, Akçay HT. The determination of molecular dynamic properties of Novel 5-oxo-1, 2, 4-triazole phthalocyanines and investigation of their urease inhibition properties. Journal of Molecular Structure. 2020:128870.

11. Arslan T, Çakır N, Keleş T, Biyiklioglu Z, Senturk M. Triazole substituted metal-free, metallo-phthalocyanines and their water soluble derivatives as potential cholinesterases inhibitors: Design, synthesis and in vitro inhibition study. Bioorganic chemistry. 2019;90:103100.

12. Demirbaş Ü, Akyüz D, Akçay HT, Koca A, Bekircan $\mathrm{O}$, Kantekin $\mathrm{H}$. Electrochemical and spectroelectrochemical study on novel nonperipherally tetra 1, 2, 4-triazole substituted phthalocyanines. Journal of Molecular Structure. 2018;1155:380-8.

13. Barut $B$, Yalçın CÖ, Demirbaş Ü, Özel A. Photochemical and in vitro phototoxic properties of $\mathrm{Zn}$ (II) phthalocyanine bearing piperidinium groups on different cell lines. Journal of Organometallic Chemistry. 2020:121358.

14. Demirbaş Ü, Pişkin $M$, Bayrak $R$, Durmuş $M$, Kantekin $H$. Zinc (II) and lead (II) phthalocyanines bearing thiadiazole substituents: Synthesis, characterization, photophysical and photochemical properties. Journal of Molecular Structure. 2019;1197:594-602.

15. Volov AN, Burtsev ID. New glycosylated platinum(II) phthalocyanine containing ribose moiety-synthesis and photophysical properties. Journal of Organometallic Chemistry. 2020:121372.

16. Baygu Y, Gök Y. A highly water-soluble zinc (II) phthalocyanines as potential for PDT studies: Synthesis and characterization. Inorganic Chemistry Communications. 2018;96:133-8.

17. Demirbaş Ü, Akyüz D, Akçay HT, Koca A, Kantekin $H$. Non-peripherally tetra substituted lead(II), nickel(II) and copper(II) phthalocyanines bearing $[1,2,3]$ triazole moeties: Synthesis, characterization and investigation of electrochemical and spectroelectrochemical properties. Journal of Molecular Structure. 2019;1176:695-702.

18. Karaca H, Sezer S, Özalp-Yaman Ş, Tanyeli C. Concise synthesis, electrochemistry and spectroelectrochemistry of phthalocyanines having triazole functionality. Polyhedron. 2014;72:147-56.

19. Demirbaş Ü, Özçifçi $Z$, Akçay HT, Menteşe E. Novel phthalocyanines bearing 1, 2, 4 triazole substituents: Synthesis, characterization, photophysical and photochemical properties. Polyhedron. 2020:114470.
20. Lever ABP, Leznoff CC. Phthalocyanines: properties and applications: New York: VCH, 1989c1996.; 1996.

21. Adebayo AI, Nyokong T. Synthesis, spectroscopic and electrochemical properties of manganese, nickel and iron octakis-(2diethylaminoethanethiol)-phthalocyanine.

Polyhedron. $2009 ; 28(14): 2831-8$.

22. Kamiloğlu AA, Akyüz D, Koca A, Acar İ. Synthesis and investigation of spectroelectrochemical properties of peripherally tetra-substituted phthalocyanine bearing 3-(4-\{[3(trifluoromethyl) benzyl] oxy $\}$ phenyl) propan-1-ol and its metallo compounds. Journal of Inclusion Phenomena and Macrocyclic Chemistry. 2018;92(1-2):223-35.

23. Nar I, Gül A, Sivaev IB, Hamuryudan E. Cobaltacarborane functionalized phthalocyanines: Synthesis, photophysical, electrochemical and spectroelectrochemical properties. Synthetic Metals. 2015;210:376-85.

24. Alemdar A, Özkaya AR, Bulut M. Synthesis, spectroscopy, electrochemistry and in situ spectroelectrochemistry of partly halogenated coumarin phthalonitrile and corresponding metalfree, cobalt and zinc phthalocyanines. Polyhedron. 2009;28(17):3788-96.

25. Akyüz D, Demirbaş Ü, Akçay HT. Synthesis, characterization and electrochemistry of 1-phenoxypropan-2-yloxy substituted phthalocyanines. Journal of Organometallic Chemistry. 2020;923:121455.

26. Demirbaş Ü, Akyüz D, Akçay HT, Koca A, Menteşe E, Kantekin $H$. Novel 1, 2, 4-triazole substituted metallo-phthalocyanines: Synthesis, characterization and investigation of electrochemical and spectroelectrochemical properties. Journal of Molecular Structure. 2018; 1173:205-12.

27. Orman EB, Arıbal A, Özkaya AR, Bulut $M$, Salan Ü. Synthesis, characterization and electrochemical properties of isoflavone substituted zinc(II), cobalt(II), and metal-free phthalocyanines. Journal of Porphyrins and Phthalocyanines. 2019;23(07n08):856-69.

28. Evans DH, O'Connell KM, Petersen RA, Kelly MJ. Cyclic voltammetry. ACS Publications; 1983.

29. Matsuda H, Ayabe Y. Zur Theorie der Randles-Sevčikschen KathodenstrahlPolarographie. Zeitschrift für Elektrochemie, Berichte der Bunsengesellschaft für physikalische Chemie. 1955;59(6):494-503.

30. Karaoğlan GK, Gümrükçü G, Koca A, Gül A. The synthesis, characterization, electrochemical and spectroelectrochemical properties of a novel, 
cationic, water-soluble $\mathrm{Zn}$ phthalocyanine with extended conjugation. Dyes and Pigments. $2011 ; 88(3): 247-56$.

31. Mack J, Stillman MJ. Photochemical formation of the anion radical of zinc phthalocyanine and analysis of the absorption and magnetic circular dichroism spectral data. Assignment of the optical spectrum of [ZnPc (-3)]. Journal of the American Chemical Society. $1994 ; 116(4): 1292-304$.

32. Nyokong T, Gasyna Z, Stillman MJ. Phthalocyanine. pi.-cation-radical species: photochemical and electrochemical preparation of [ZnPc (-1).+ in solution. Inorganic Chemistry. $1987 ; 26(4): 548-53$.

33. Alemdar A, Özkaya AR, Bulut $M$. Preparation, characterization, electrochemistry and in situ spectroelectrochemistry of novel a-tetra [7oxo-3-(2-chloro-4-fluorophenyl) coumarin]substituted metal-free, cobalt and zinc phthalocyanines. Synthetic metals. 2010;160(1314):1556-65.
34. Ough EA, Crebera KA, Stillman MJ. Electrochemistry and spectroscopy of magnesium octaethyltetraazaporphyrin and magnesium octakis (methylthio) tetraazaporphyrin. Inorganica chimica acta. $1996 ; 246(1-2): 361-9$.

35. Rollmann LD, Iwamoto RT. Electrochemistry, electron paramagnetic resonance, and visible spectra of cobalt, nickel, copper, and metal-free phthalocyanines in dimethyl sulfoxide. Journal of the American Chemical Society. 1968;90(6):1455-63.

36. Akyüz D, Demirbaş Ü, Akçay HT. Synthesis, characterization and electrochemistry of 1-phenoxypropan-2-yloxy phthalocyanines. Journal of Organometallic Chemistry. 2020:121455.

37. Kryjewski M, Rebis T, Milczarek G, Gdaniec Z, Goslinski T, Mielcarek J. Magnesium (ii) 1-(1adamantylsulfanyl) phthalocyanine-synthesis, photochemical and electrochemical properties. New Journal of Chemistry. 2016;40(11):9774-80. 
Akyüz D. JOTCSA. 2021; 8(1): 9-20.

RESEARCH ARTICLE 